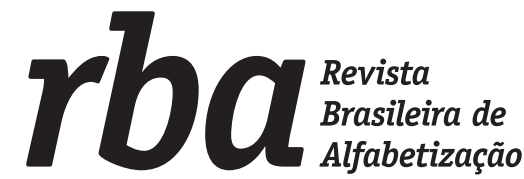

\section{LETRAMENTOS FAMILIARES NA POLÍTICA BRASILEIRA DE ALFABETIZAÇÃO}

\author{
FAMILY LITERACIES IN THE BRAZILIAN POLICY OF READING \\ AND WRITING LEARNING
}

\author{
Wagner Rodrigues Silva \\ Universidade Federal do Tocantins \\ wagnersilva@uft.edu.br \\ Juliana de Sousa Delfino \\ Universidade Federal do Tocantins \\ julianadelfino715@gmail.com
}

\section{RESUMO}

Investigamos o conceito de literacia familiar apresentado na política brasileira oficial de alfabetização na segunda década do século XXI. O principal documento investigado é o guia Conta Pra Mim, que sistematiza um programa com propostas de práticas de literacia familiar, conforme nomenclatura assumida oficialmente. Este estudo se caracteriza como uma pesquisa documental orientada predominantemente por pressupostos teóricos dos estudos dos letramentos, desenvolvidos em bases antropológicas e interpretativistas. Está situada na interface da Ciência da Educação e Linguística Aplicada. O programa de literacia ignora contribuições dos estudos dos letramentos informados por abordagens críticas. São sugeridas práticas de literacia familiar marcadas por reflexões sobre o sistema alfabético da escrita. Tais práticas se assemelham a abordagens formais preparatórias para a alfabetização.

Palavras-chave: escolarização; letramentos emergentes; política pública.

\begin{abstract}
We investigated the concept of family literacy presented in the official Brazilian literacy policy in the second decade of the $21^{\text {st }}$ century. The main document investigated is the Conta Pra Mim guide, which systematizes a program with proposals for family literacy practices, according to officially accepted nomenclature. This study is a documentary research guided predominantly by theoretical assumptions from studies of literacies, developed on anthropological and interpretative bases. It is located at the interface of Education Science and Applied Linguistics. The literacy program ignores contributions from studies of literacies informed by critical approaches. Some family literacy practices are suggested, marked by reflections about the alphabetic writing system. Such practices resemble formal preparatory approaches to reading and writing learnings.
\end{abstract}

Keywords: schooling; emergent literacies; public policy. 


\section{INTRODUÇÃO}

Em 2019, o governo federal brasileiro publicou a Política Nacional de Alfabetização - PNA (BRASIL, 2019a) a partir do Decreto $n^{\circ}$ 9.765, de 11 de abril de 2019 (BRASIL, 2019b)․ Como uma das estratégias de implementação, criou-se o programa Conta pra Mim, descrito em um Guia de Literacia Familiar (BRASIL, 2019c), amparado pela Portaria n 421, de 23 de abril de 2020 (BRASIL, 2020). Conforme mostrado por Silva (2021), percebe-se nessa política um esforço para invisibilizar as contribuições pedagógicas originárias de estudos dos letramentos, fundamentados em abordagens científicas interpretativistas de base antropológica, e produzidos no Brasil sob influência teórica internacional. Em contraposição, assume-se oficialmente o termo literacia, de influência europeia, ignorado por alfabetizadoras ${ }^{2}$ brasileiras e incomum em estudos nacionais desenvolvidos na Ciência da Educação ou na Linguística Aplicada, principais campos investigativos sobre o assunto (KLEIMAN, 1995; MARINHO; CARVALHO, 2010; SILVA, 2021).

Considerando os referidos documentos oficiais - decreto, caderno, guia e portaria - como objetos de análise, investigamos a caracterização da abordagem do que se denomina literacia familiar na configuração da atual política oficial de alfabetização para o Brasil. É extensa a produção científica brasileira em torno dos estudos dos letramentos e da alfabetização (KLEIMAN; SIGNORINI, 2000; MORAIS, 2012; 2019; ROJO, 1998; SILVA, 2019; 2020; SOARES, 2003a; 2009; 2016; 2020; só para citar alguns) e são essas as literaturas especializadas acessíveis às professoras da educação básica, as quais não se utilizam da denominação literacia nem tampouco da literacia familiar ${ }^{3}$. Nesse sentido, faz-se necessário problematizar tal abordagem para entender o que se compreende por literacia familiar na política oficial de alfabetização e, posteriormente, pontuar possíveis implicações da abordagem subjacente a tal conceito no cotidiano de atores sociais envolvidos na política - crianças, educadoras, pais, figuras parentais ou responsáveis.

Esclarecer conceitos subjacentes à referida abordagem e mostrar aproximações e distanciamentos, entre algumas literaturas científicas e os documentos oficiais selecionados, configuram-se um empreendimento fundamental para entender a PNA (BRASIL, 2019a) e para contribuir com a formação inicial e continuada de professoras alfabetizadoras. Para tanto respondemos as seguintes perguntas ao longo deste artigo: o que são letramentos familiares na literatura científica selecionada? O que é literacia familiar na PNA? Que práticas de leitura e escrita caracterizam a literacia familiar na PNA?

Este estudo foi desenvolvido no grupo de pesquisa Práticas de Linguagens - PLES (UFT/CNPq) a partir de contribuições teóricas originárias de diferentes disciplinas ou campos do conhecimento, dentre os quais destacamos a Ciência da Educação e a Linguística Aplicada. Compreendemos a linguagem como prática social e defendemos a legitimação de diferentes letramentos presentes em nossa sociedade marcada por tensões, conflitos e desigualdades diversas. Assim, podemos afirmar que os distintos letramentos representam culturas de origens diversificadas, mais ou menos visibilizadas por inúmeros fatores.

\footnotetext{
1 O primeiro autor deste artigo agradece ao Conselho Nacional de Desenvolvimento Científico e Tecnológico (CNPq) pela Bolsa de Produtividade em Pesquisa concedida (CNPq 304186/2019-8), o que contribuiu para a realização da pesquisa apresentada neste texto. Uma versão preliminar desta pesquisa foi apresentada como Trabalho de Conclusão de Curso pela segunda autora, na Licenciatura em Pedagogia, Câmpus de Palmas.

2 Nesta pesquisa, o uso do feminino como referência às alfabetizadoras se justifica pela predominância das mulheres como professoras na Educação Infantil ou Ensino Fundamental I.

3 Neste estudo, utilizamos o termo literacia quando nos referirmos aos documentos oficiais ou, ainda, fizermos citações diretas de pesquisas desenvolvidas em Portugal. Assumimos o termo letramento(s), conforme sempre foi utilizado nas pesquisas científicas desenvolvidas no Brasil e priorizamos a forma no plural por entendermos que diversas são as práticas sociais mediadas pela escrita. Detalhes sobre a escolha do termo literacia na PNA (BRASIL, 2019a) podem ser observados em Silva (2021).
} 
Este artigo está organizado em três principais partes, além desta Introdução, das Considerações finais e Referências. Em Letramentos além do espaço escolar, apresentamos e comparamos concepções de letramentos emergentes e letramentos familiares, além de outros pressupostos teóricos que subsidiaram o exame dos documentos selecionados para o estudo. Em Procedimentos metodológicos, descrevemos os documentos analisados na medida em que caracterizamos este estudo como uma pesquisa documental e bibliográfica, desenvolvida a partir de uma abordagem qualitativa. Por fim, em Escolarização de interações familiares, compartilhamos a análise crítica desenvolvida com exemplificações de algumas sequências textuais reproduzidas a partir dos documentos investigados.

\section{LETRAMENTOS ALÉM DO ESPAÇO ESCOLAR}

O conceito de educação é amplo e seu sentido geralmente é relacionado ao espaço institucional da escola, porém, o ato de educar também envolve a participação das famílias e de outras instituições da sociedade, a exemplo de postos de saúde, grupos religiosos, associações comunitárias ou organizações sociais. Quando desencadeada na escola, tem-se a educação formal, ao passo que, quando proporcionada fora desse espaço, tem-se a educação informal. Conforme Gohn (2006, p. 28),

A educação formal é aquela desenvolvida nas escolas, com conteúdos previamente demarcados; a informal como aquela que os indivíduos aprendem durante seu processo de socialização - na família, bairro, clube, amigos etc., carregada de valores e culturas próprias, de pertencimento e sentimentos herdados.

No ensino formal, as professoras estão habilitadas a desenvolverem práticas pedagógicas orientadas por literaturas especializadas e diretrizes oficiais. Essas profissionais acumulam saberes da prática ao longo dos anos de trabalho no magistério, elaboram planos de aula, delimitam objetivos a serem alcançados. Por parte das professoras, espera-se que haja uma intencionalidade reconhecida na situação educativa planejada (FREIRE, 2008). Já na educação informal, instaurada na família, na comunidade, centros religiosos, dentre outros espaços sociais, são instauradas trocas de aprendizagem espontâneas. Ao serem propostas práticas em que a família deve, sistematicamente, chamar a atenção da criança para as formas da escrita ou os sons representados pelas letras, por exemplo, demanda-se alguma formalização de interações cotidianas na família.

Neste estudo, compreendemos situação educativa de acordo com Paulo Freire (2008, p. 30-32), que a caracteriza pela presença de alguns elementos constitutivos: (1) "sujeito, o educador ou educadora, que tem uma determinada tarefa específica que é a tarefa de educar"; (2) "presença de educandos, de alunos"; (3) "espaço pedagógico"; (4) "como não há espaço sem tempo, então o tempo pedagógico é outro elemento"; (4) "conteúdos curriculares, os elementos programáticos da escola, chamamos de objetos cognoscíveis, objetos estes que os jovens que se formam para ser professor ou professora devem conhecer".

No contexto educacional brasileiro, as discussões em torno da alfabetização sempre estiveram presentes, pois o analfabetismo tem se demonstrado como um grande desafio ao país ${ }^{4}$. Evidências

4 A reprovação escolar também já se constituiu como um agravante do processo de alfabetização. Na década de 80 do século passado, Cagliari (1986, p. 26-27) chamou a atenção para um índice de reprovação no final do primeiro ano: "cerca de 50\%. Nos outros anos (são tantos!...), a exclusão dos alunos faz com que as turmas se reduzam a uns poucos alunos. A escola não é um meio homogeneizador das diferenças sociais, mas um estímulo para isso. O argumento que usa para o que faz, é a capacidade diferente de cada um para aprender, o que não passa de uma desculpa sem fundamento, mas é conveniente para acobertar seus preconceitos e reais intenções". 
desse desafio são as metas assumidas a partir do atual Plano Nacional de Educação (PNE) ${ }^{5}$, dentre as quais destacamos a universalização do acesso à escola para crianças e jovens em idade escolar e, inclusive, a alfabetização de todas as crianças até o $3^{\circ}$ ano do Ensino Fundamental. Para além do desafio da alfabetização, a partir dos anos 80, entraram também em pauta discussões em torno das abordagens dos letramentos, assumidas para compreender e promover o domínio dos usos da leitura e da escrita no contexto escolar e a participação proveitosa das pessoas em outras práticas sociais mediadas pelo uso da tecnologia da escrita (KLEIMAN, 1995; SOARES, 2003b; 2009)6. Assim, foi realçada a demanda pelo deslocamento do letramento informado pelo modelo autônomo para letramentos diversos, na perspectiva do modelo ideológico, conforme postulado por Street (2010; 2014). Foi reconhecida a necessidade de valorização das práticas de leitura e de escrita características de situações interativas de outros espaços sociais, diferentes dos contextos de instrução formal.

O modelo autônomo corresponde a uma concepção homogeneizada da cultura escrita. Uma compreensão restrita dos letramentos escolares seria a principal referência desse modelo. Nesse sentido, valoriza-se o que é trabalhado pela tradição escolar como o suficiente para responder às inúmeras demandas sociais de usos da leitura e da escrita. Trata-se de um modelo simplificado e linear atrelado aos letramentos escolares, quando as práticas pedagógicas são responsáveis pela realimentação da própria dinâmica institucional. Ou seja, as práticas institucionais de linguagem garantiriam o trânsito dos aprendizes pelos diferentes níveis de escolarização.

Já o modelo ideológico pressupõe a visibilização de vários letramentos. Não basta ter uma referência legitimada de letramento, característica de uma esfera social dominante, como as práticas de escrita tipicamente escolares. Busca-se visibilizar ou valorizar culturas escritas diversas, a exemplo das desenvolvidas em comunidades ou grupos subalternizados na sociedade. Esse último modelo possibilita apreender relações conflituosas ou de poder atreladas às culturas da escrita? .

O processo de alfabetização de crianças compreende o trabalho planejado e necessário para garantir o aprendizado da leitura e da escrita, portanto, também se configura como um tipo de letramento e, por suas particularidades institucionais, podemos caracterizá-lo como um letramento escolar. Nesse contexto, porém, fala-se em alfabetização e letramento como abordagens pedagógicas distintas e inseparáveis (SOARES, 2003a; 2009; 2020). Em outras palavras, recomenda-se o ensino da leitura e da escrita tomando-se como referência a diversidade de situações interativas mediadas por textos escritos. Quando alguém sabe ler, mas não consegue interpretar textos extensos ou mais complexos, essa pessoa pode ser considerada alfabetizada, ainda que possa ser, mais precisamente, caracterizada como analfabeta funcional. Ou seja, essa pessoa possui dificuldades para se utilizar da escrita para alguns propósitos específicos, a exemplo da compreensão ou da produção de alguns textos escritos moldados em gêneros não familiares a essa pessoa.

5 O PNE elenca vinte metas para a educação a serem alcançadas na década de 2014 a 2024, a partir da colaboração direta dos municípios, estados, Distrito Federal e União (BRASIL, 2014).

6 Conforme Kleiman (2000, p. 19), compreendemos letramentos "como o conjunto de práticas sociais relacionadas ao uso, à função e ao impacto da escrita na sociedade, diferenciando esse conceito do conceito de alfabetização, o qual é mais restrito, em geral interpretado como processo de aquisição do código da escrita e domínio individual desse código".

7 Nos termos de Street (2010, p. 36), no modelo autônomo, "letramento é uma coisa autônoma, separada e cultural; uma coisa que teria efeitos, independentemente do contexto. Nessa concepção, alguém poderia sentar-se em grandes cidades, na UNESCO, em Paris, por exemplo, e criar um programa de alfabetização que serviria para todos os lugares". Em outra perspectiva, o autor afirma que "as pessoas podem estar envolvidas em uma forma e não na outra, suas identidades podem ser diferentes, suas habilidades podem ser diferentes. Por isso, selecionar só uma variedade de letramento pode não ter efeitos que se espera. Refiro-me a esse modelo como um modelo ideológico; não só um modelo cultural, embora seja isso, mas ideológico porque há poder nessas ideais. Esses modelos são poderosos" (p. 37; itálico do original). 
O modelo ideológico a que fizemos referência a partir de Street (2010; 2014) possibilita o reconhecimento do que pode ser denominado letramentos familiares (marcamos nossa preferência pelo plural), que, na perspectiva assumida nesta pesquisa, podem ser desenvolvidos e incentivados na interação diária entre familiares. Tendem a ser promovidos em práticas espontâneas, não exigem formalidades e acontecem na diversidade de práticas diárias culturalmente marcadas.

A título de ilustração, ressaltamos que crianças, jovens e adultos interagem em torno de atividades de colagem de figurinhas em álbuns com curiosidades sobre o percurso profissional dos jogadores do último campeonato. Algumas crianças interagem com adultos no esforço de compreensão do desafiador manual de montagem do recém-comprado equipamento eletrônico. As famílias religiosas se reúnem para estudos de livros sagrados, nos próprios lares, em casas de amigos, em templos religiosos e, mais recentemente, em transmissões síncronas a partir de redes sociais. Situações como essas são informadas por práticas de leitura e escrita, são despretensiosas e instauram-se naturalmente, sem finalidades pedagógicas.

Assim, os letramentos familiares "não precisa[m] ser associado[s] com escolarização ou com pedagogia" (STREET, 2014, p. 127). As práticas de letramentos familiares acontecem de forma espontânea e informal, são desenvolvidas no contexto particularizado em que a criança está inserida e no que poderá ser percorrido por ela ao longo da vida. Como uma agência de letramento, a escola deve atentar para as diferentes práticas sociais desenvolvidas nas diversas composições familiares, aproveitando a heterogeneidade dessas realidades (KLEIMAN, 1995).

Os trabalhos investigados sobre letramentos familiares nos mostraram pesquisas que foram desenvolvidas em países europeus e da América do Norte, a exemplo de Portugal, Reino Unido, Canadá e Estados Unidos (RESENDE; FIGUEIREDO, 2018). Algumas pesquisas científicas portuguesas revelaram que as experiências familiares interativas mediadas pela escrita são importantes para o desenvolvimento da linguagem oral e escrita, além de fortalecer os laços afetivos entre os adultos e as crianças, podendo ter desdobramentos promissores ao longo da vida, conforme almejado a partir de políticas oficiais ou, inclusive, os interesses particulares das famílias, comunidades ou coletivos (MATA, 2012; COELHO, 2011; RESENDE e FIQUEIREDO, 2018; VILHENA, 2014) ${ }^{8}$.

Mata (2012) afirma que embora seja valorizada a importância das famílias no desenvolvimento dos letramentos das crianças, a maneira como as famílias irão participar nem sempre é unânime. A autora afirma que alguns trabalhos definem a participação das famílias apenas como reforço e valorizaçao de práticas ou atividades escolares, os lares funcionam como uma extensão das escolas, o que podemos caracterizar como influência do modelo autônomo. Já outros trabalhos definem a participação das famílias de forma mais ampla, valorizando práticas do cotidiano que já fazem parte dos próprios contextos familiares (COELHO, 2011; RESENDE; FIQUEIREDO, 2018; VILHENA, 2014). Os trabalhos também revelam que a maioria dos projetos e pesquisas sobre letramentos familiares foram desenvolvidos junto a famílias de classes sociais desfavorecidas.

8 Nos termos de Resende e Figueiredo (2018, p. 10), "as interações das crianças com os pais/figuras parentais através da realização de atividades promotoras de literacia emergente no contexto familiar promovem também uma vinculação positiva com as pessoas mais significativas. Verifica-se ainda que a qualidade dessa relação e da estimulação precoce da criança com essas mesmas práticas, nomeadamente com a leitura partilhada e em voz alta de livros em contexto familiar, é significativamente associada, à adoção de promoção e comportamentos de saúde". 
Para o desenvolvimento de letramentos familiares, as pesquisas portuguesas apontam que se devem considerar o ambiente em que as práticas de letramento serão desenvolvidas, a escolaridade da família e o tempo que a família tem disponível para a interação com as crianças. Outro fator importante são os atores dos letramentos familiares. Esses não se restringem à família das crianças, estão envolvidos profissionais que trabalham com crianças - assistentes sociais, fonoaudiólogas, enfermeiras, médicas, professoras, psicólogas -, que podem ser agentes conscientes na promoção de letramentos familiares (MATA, 2012; RESENDE; FIGUEIREDO, 2018).

No âmbito da Enfermagem, Resende e Figueiredo (2018), conforme já mencionamos, fizeram um estudo bibliográfico de pesquisas desenvolvidas em diferentes países. Investigaram algumas contribuições de práticas de leitura e escrita, no seio de algumas famílias, para o que denominam de letramento emergente ou precoce, além das contribuições para a saúde da criança. Parecem assumir uma concepção de letramento emergente resultante de práticas ou atividades informais (por não tematizarem práticas escolares) mediadas pela escrita; corresponde a "um conjunto de conhecimentos, competências e atitudes precursoras do desenvolvimento da literacia" (RESENDE; FIGUEIREDO, 2018, p. 2). Tal concepção se contrapõe ao conceito formal de letramento emergente assumido por Viana, Ribeiro e Barrera (2017) em função do aprimoramento das práticas escolares na Educação Infantil, fortalecendo os conhecimentos linguísticos das crianças, construindo bases mais consistentes para o processo formal e subsequente de alfabetização. De acordo com Resende e Figueiredo (2018, p. 9), o letramento familiar pode contribuir com a formação integral da criança:

Do ponto de vista do desenvolvimento físico, as atividades promotoras do desenvolvimento da literacia emergente traduzem ganhos ao nível da motricidade fina (e.g. folhear e apontar), da motricidade grosseira (e.g. pegar e o abrir o livro, lidar com jogos), da lateralidade e da coordenação espácio-temporal. O contacto sistemático com o material escrito no contexto familiar (receitas, livros, jornais, revistas, lista de compras, convites, jogos), possibilita o desenvolvimento na criança de competências e capacidades cognitivas que se enquadram nos três grandes domínios da literacia emergente: linguagem oral, linguagem escrita e motivação para a leitura e para a escrita emergente (RESENDE; FIGUEIREDO, 2018, p.9).

Podem ser inúmeras as contribuições de uma política oficial para desenvolver os letramentos familiares, desde que sejam valorizadas as práticas do cotidiano das crianças, dentro das realidades e contextos sociais, legitimando as singularidades e os distintos formatos de famílias. As práticas de letramentos familiares recorrentes em pesquisas científicas correspondem às contações de histórias para as crianças, o que, para algumas famílias, antecedem o horário de dormir. As atividades informais de leitura e escrita resultam num processo fundamental para o desenvolvimento dos letramentos das crianças, como afirma Vilhena (2014):

No entendimento da concepção de envolvimento parental e num nível mais específico das aprendizagens dos filhos, os pais devem iniciar as actividades de leitura e escrita numa fase muito precoce, muito antes mesmo da entrada dos filhos na vida escolar, sendo que a sua influência neste processo vai ser fundamental na aquisição de conhecimentos de Literacia por parte das crianças. (VILHENA, 2014, p.11).

A autora ainda considera que o envolvimento parental está relacionado a diversos fatores, como as crenças familiares sobre a importância da leitura, o nível de escolaridade das famílias e a relação que se contrói entre famílias, crianças e escolas. Ainda sobre a importância da leitura para as crianças, Coelho (2011, p. 35) afirma que "é tarefa da Família e do Educador abrir à criança as possibilidades de poder penetrar num texto com prazer e capacidade crítica. E esta é uma tarefa de toda a vida". 
Assim como os trabalhos sobre letramentos familiares desenvolvidos em outros países, as pesquisas brasileiras tendem a focalizar crianças e famílias pobres, pois a leitura e escrita podem se configurar como atividades decisivas para o sucesso pessoal ou profissional idealizado. Comparando - Brasil com os outros países, faz-se necessário considerar as especificidades dos nossos problemas sociais. No contexto brasileiro, destacamos as pesquisas de Brito (2016), Mendonça (2017a; 2017b) e Santos (2015) $)^{9}$, que chamam a atenção para a importância do papel da professora como uma das principais agentes para o incentivo de letramentos familiares.

O projeto de letramento familiar desenvolvido por Mendonça (2017a; 2017b), em uma comunidade da região metropolitana de Natal, no Estado do Rio Grande do Norte, envolveu a família e a escola; revelou que mesmo as professoras julgando necessária a participação das famílias na instituição de ensino, essas últimas apresentaram dificuldade em participar das reuniões de pais e mestres por falta de tempo, o que se justificava pela jornada de trabalho exaustiva ou atividades domésticas. Ao conhecer as realidades das famílias atendidas pelos projetos de letramentos familiares, percebeu-se que mesmo as famílias entendendo a importância da leitura, esta não era uma prática comum na comunidade. Algumas justificativas para o pouco contato com a leitura por parte das famílias, além da falta de tempo mencionada, eram a renda e a escolaridade: "Compreendemos que quanto menor é a renda familiar ou o grau de escolaridade, menos a pessoa lê. Logo, percebemos que não se trata de desvalorização ou desinteresse da leitura pelos alunos, mas da falta de acesso a ela" (MENDONÇA, 2017b, p.16) ${ }^{10}$.

As pesquisas estavam voltadas para solucionar os problemas apresentados pelos participantes, propondo ações que condiziam com as formas de vidas das famílias. Os projetos apresentaram em comum o propósito de melhoria da realidade dos envolvidos, estreitando relações entre famílias, comunidades e escolas, focado na participação de pessoas de baixa renda. Santos $(2015$, p. 23) ressalta que o letramento familiar é pouco focalizado no Brasil: "as discussões sobre o letramento familiar estão em fase de construção, pois há poucas pesquisas publicadas seja em dissertações, teses ou livros tratando desta temática".

Nesta pesquisa, compreendemos que os letramentos familiares são praticados nos lares antes do nascimento das crianças, e atravessam toda a vida das pessoas. São práticas informais de leitura e escrita no espaço doméstico e envolvidas em interações orais ${ }^{11}$. Já os letramentos emergentes,

9 Os trabalhos correspondem a pesquisas de mestrado orientadas por Maria do Socorro Oliveira (UFRN) e fizeram parte do projeto "O habitus de estudar: construtor de uma nova realidade na educação básica da Região Metropolitana de Natal”, coordenado por Moises Alberto Calle Aguirre (UFRN/CNPq). Os subprojetos desenvolvidos possibilitaram aos alunos, escolas, comunidades e famílias acreditarem numa educação de melhor qualidade a partir de projetos educacionais voltados para letramentos familiares.

10 Conscientes do acesso restrito, por parte da população mais pobre, a conteúdos impressos, a exemplo de livros, revistas e jornais, lembramos que, recentemente, em defesa da taxação dos livros a partir da proposição de uma reforma tributária, o Ministro da Economia do Brasil, Paulo Guedes, menosprezou políticas que pudessem contribuir com o acesso a livros pelos brasileiros com baixo poder aquisitivo. Nas palavras do ministro: os mais pobres "num primeiro momento, quando fizeram o auxílio emergencial [recurso repassado a pessoas mais vulneráveis durante a pandemia da Covid-19], estavam mais preocupados em sobreviver do que em frequentar as livrarias que nós frequentamos". Ainda segundo a Agência Senado, "na opinião do presidente da Frente Parlamentar Mista em Defesa do Livro, senador Jean Paul Prates (PT-RN), a tributação de livros não é um prejuízo apenas para o segmento editorial, mas para o Brasil como um todo. Ele lembra que a média de leitura no Brasil é muito baixa - 4,96 livros lidos por pessoa, anualmente — e cobrar $12 \%$ de impostos vai encarecer o produto e distanciar ainda mais os livros da população". Disponível em: https://www12.senado.leg.br/noticias/materias/2020/08/11/reforma-tributaria-pode-fazer-livro-ficar-mais-caro. Acesso em: 10 jan. 2021.

11 Sustentamos a hipótese de que desde a mais tenra idade, a interação parental se mostra importante não apenas para o desenvolvimento de letramentos familiares, mas para o aprendizado da língua(gem). Sobre esse último, Halliday e Matthiessen (2014, p. 26) afirmam que "Quando as crianças aprendem como significar, elas começam com um sistema semiótico muito singelo, a protolíngua(gem), usualmente algumas vezes na segunda metade do primeiro ano de vida delas. [...], e nós levantamos a hipótese de que a língua(gem) se desenvolve da mesma maneira. [...] Este sistema é organizado em dois planos em estratos, conteúdo e expressão; mas nenhum é internamente estratificado: conteúdo é delineado diretamente em direção à expressão (vocal ou gestual). Esta protolíngua(gem) é uma língua da criança em vez de uma língua materna; ela não é ainda como a língua(gem) adulta falada em torno das crianças pequenas. As crianças desenvolvem suas protolínguas(gens) na interação com seus cuidadores imediatos, gradualmente expandindo os potenciais das suas protolínguas(gens). Fazendo assim, elas aprendem os princípios dos significados" (destaque do original; tradução livre do inglês). 
compreendemos como práticas de caráter formal planejadas e implementadas por professoras da educação infantil. Eles ajudam no processo propriamente dito de alfabetização. No contexto focalizado da política brasileira de alfabetização, quando falamos sobre os letramentos escolares, referimos ao processo de alfabetização trabalhado de forma explícita por professoras, dentro da escola. Para efeitos de estudo, particularizamos os letramentos familiares, emergentes e escolares, conforme a Figura 1, mas o que efetivamente temos são inúmeros letramentos e eles se complementam.

Figura 1 - Letramentos

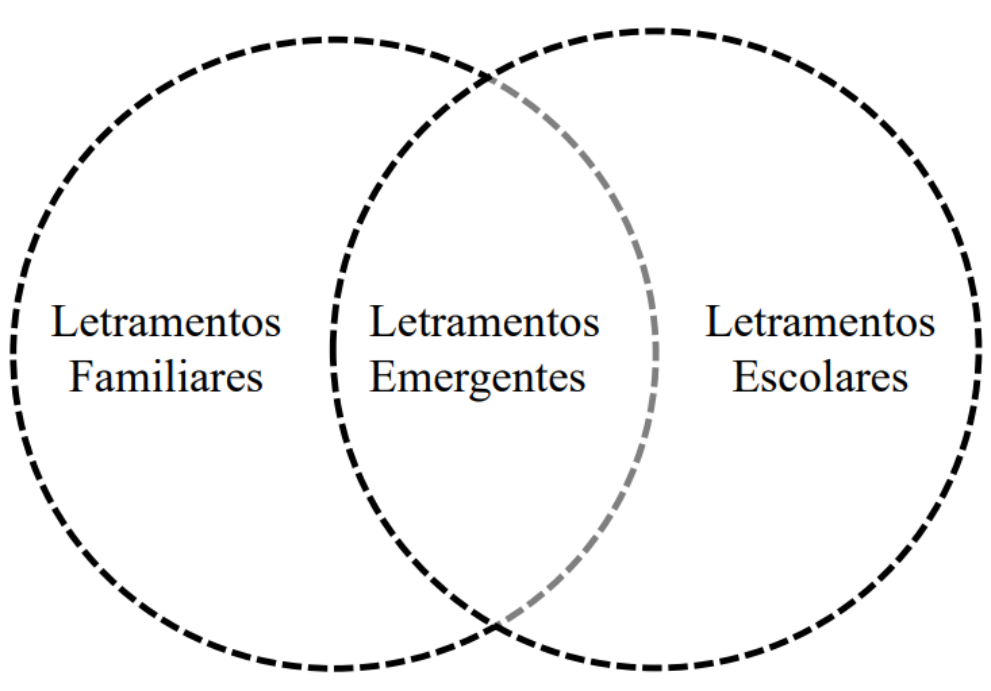

Fonte: autoria própria

Os letramentos emergentes não deixam de ser escolares, pois são sistematizados na referida instituição. São as práticas desenvolvidas na escola de Educação Infantil para preparar as crianças para o processo efetivo de alfabetização. De alguma forma, configuram-se na modalidade formal de ensino, pois acontecem na escola sob a mediação de professoras. Quanto aos letramentos escolares, estariam mais alinhados às práticas de ensino iniciadas no contexto de alfabetização, mas comprometido com o ensinar e já se distanciando do cuidar característico da Educação Infantil.

Viana, Ribeiro e Barrera (2017) desenvolvem um programa de letramentos emergentes para as crianças do último ano da Educação Infantil no Brasil e em Portugal, a fim de proporcionar às professoras atuantes nesse fase um conjunto de atividades consideradas facilitadoras da aprendizagem de leitura e escrita. Para as autoras, os letramentos emergentes exprimem o sentido de emergir desde cedo a aprendizagem e o desenvolvimento de crianças pequenas, que já estão inseridas em uma sociedade letrada, em que as práticas de letramento iniciadas no lar de maneira não intencional passam a ter formalidade na Educação Infantil. Não correspondem ao ensino direto da leitura e escrita a crianças na Educação Infantil, mas ao desenvolvimento da percepção das funções sociais da escrita, compreender e interpretar, familiarizando-se, inclusive, com o sistema de escrita alfabética da língua materna. De acordo com Barrera, Ribeiro e Viana (2017, p.6):

O trabalho desenvolvido em educação infantil, em especial no que diz respeito ao letramento emergente, não implica uma abordagem escolarizante (em que se antecipa o ensino explícito da leitura e da escrita), mas sim a estruturação de um conjunto de ações que contribuam para o desenvolvimento da linguagem oral, da descoberta do princípio alfabético, da funcionalidade da leitura e da escrita, da consciência fonológica e da motivação para a leitura - competências consideradas facilitadoras da alfabetização. 
Este trabalho deve acontecer de forma lúdica, é um facilitador e não pode ser considerado como determinador na aprendizagem da leitura. Viana, Cruz e Cadime (2017) afirmam que as práticas de letramentos familiares podem promover o desenvolvimento de letramentos emergentes, porém, a forma como a família irá desenvolver essas práticas pode acabar invertendo ou confundindo os papéis da família e das escolas. Isso pode se configurar no que Street e Street (2014, p.121) chamam de escolarização ou pedagogização do letramento, compreendida como uma tentativa de inferiorizar os letramentos que não são escolares. Os autores afirmam que "o letramento ficou associado às noções educacionais de Ensino e Aprendizagem e àquilo que professores e alunos fazem nas escolas, em detrimento dos vários outros usos e significados de letramento evidenciados na literatura etnográfica comparativa" (STREET; STREET, 2014, p. 121-122).

No programa Conta Pra Mim (BRASIL, 2019c), ao proporem habilidades que focam na escrita nos lares, por exemplo, pode-se minimizar a natureza espontânea dos letramentos, e supervalorizar práticas com intencionalidades. Por não ter formação pedagógica, a família poderá estabelecer uma relação negativa do processo de alfabetização como consequência da antecipação intencional. A alfabetização de crianças é um processo complexo: "A leitura e a escrita exigem ensino formal, o que prova a sua dependência cultural e a sua complexidade" (VIANA; CRUZ; CADIME, 2017, p. 18). $\mathrm{Na}$ perspectiva da referida política, os letramentos familiares tendem a ficar relacionados a práticas escolares.

É inegável a importância do papel da família na vida das crianças, reafirmado por documentos como a Constituição Federal de 1988, Lei de Diretrizes e Bases da Educação de 1996 e o Estatuto da Criança e do Adolescente de 1990, que asseguram os direitos e deveres da família na participação da vida escolar das crianças. Dentre os papéis que a família deve exercer, está a providência de uma escola que possa atender às necessidades das crianças, garantindo que essas últimas tenham segurança, afeto e respeito naquele espaço, cabe também à família o dever de orientar as crianças ao cumprimento de acordos estabelecidos pela escola, participar de reuniões, acompanhar o trabalho pedagógico ou atividades.

Conforme realçado por Morais (2012, p. 87), "o processo de letramento não se inicia na escola nem no primeiro ano do ensino fundamental [...] ele durará toda a vida". Em outros termos, o contato com a língua escrita acontece antes mesmo de a criança ingressar no ensino formal. Na sociedade atual, a criança já está inserida no mundo da escrita de diferentes maneiras, considerando, por exemplo, a existência de outdoors nas ruas, de marcas em roupas e fachadas de lojas, além de atividades como folhear livros ou revistas. Estes e inúmeros outros contatos são importantes, acontecem ainda na família e podem ocorrer de forma não intencional. A escola, por sua vez, tem o papel de estabelecer pontes entre acontecimentos dentro e fora do ambiente escolar. A referida instituição precisa promover um espaço de aprendizagem com intencionalidade.

Assim como as escolas da Educação Infantil são importantes para a inserção das crianças no mundo da escrita, a família também exerce um importante papel na vida das crianças, principalmente no desenvolvimento da linguagem oral: "Falar com as crianças é o primeiro passo para permitir a aquisição da linguagem oral. [...] a estimulação do bebê alia o toque, a cor e o movimento ao som, com as verbalizações dos pais a organizar as rotinas do dia a dia e a dar sentido às tentativas de vocalização das crianças" (VIANA, 2017, p. 31). Família e escola ocupam papéis diferentes na vida escolar das crianças, mas ambos devem garantir que elas tenham suas necessidades atendidas, de maneira que o futuro das crianças não seja comprometido por falta do cumprimento das responsabilidades específicas de cada agente social. 
Na Linguística Aplicada, Kleiman (1995) afirma que a oralidade faz parte dos objetos de análise dos estudos dos letramentos, pois pode ter alguma relação com a tecnologia da escrita. Conforme já afirmamos, o processo de letramento das crianças tem início antes mesmo de elas serem alfabetizadas. Elas se envolvem em eventos de letramento, como a escuta de histórias lidas, quando se relacionam fatos narrados com situações do cotidiano ${ }^{12}$. Por estar relacionada à escrita, essa oralidade é chamada de oralidade letrada. Esse evento é uma prática que pode acontecer em famílias de diversas classes sociais. Práticas desse tipo são diferenciadas por diversos fatores, dentre os quais destacamos o poder aquisitivo e a escolaridade das famílias.

De acordo com Kleiman (1995), há uma tendência de as famílias menos favorecidas não reconhecerem, nas situações cotidianas, oportunidades de verbalizar e retomar algumas leituras que já foram feitas para as crianças. Não conseguem assemelhar o mundo real com as estórias dos livros. Para algumas famílias excluídas, o desenvolvimento de uma relação mais estreita com a escrita depende de investimentos na educação de adultos, que, por sua vez, não são beneficiários prioritários da política de alfabetização focalizada neste artigo (BRASIL, 2019a) ${ }^{13}$.

Algumas habilidades desenvolvidas por crianças, antes de ingressar no espaço formal de educação, não são valorizadas pela escola. Conforme afirma Terzi (1995, p. 95), "A criança que não domina as habilidades privilegiadas pela escola não é vista conforme seu desenvolvimento, mas conforme o que Ihe falta para atingir o padrão pressuposto pela escola, ou seja, o seu déficit". A atual política de alfabetização abre margem para a exclusão das comunidades em que as práticas de oralidade são mais frequentes e valorizadas, diferentemente das práticas de escrita, quando deveríamos esperar que as escolas se orientassem por habilidades já adquiridas pelos alunos.

Finalmente, reiteremos que os letramentos como práticas sociais não se limitam apenas ao contexto escolar, propagam-se por diversos contextos ou espaços sociais dos quais os indivíduos fazem parte, como o domínio ou a esfera familiar problematizada mais diretamente neste estudo. Nas famílias, as práticas de letramentos tendem a acontecer espontaneamente em interações cotidianas, a exemplo do momento em que as pessoas escrevem uma lista de compras sob a curiosidade ou observação atenta das crianças. Assim, essas últimas descobrem que se escreve da esquerda para a direita, de cima para baixo e que as palavras da lista são organizadas uma abaixo da outra e que são justapostas a numerais. São eventos diversos que acontecem diariamente, envolvendo práticas de leitura e escrita nos lares.

\section{PROCEDIMENTOS METODOLÓGICOS}

Este estudo se caracteriza como uma pesquisa documental, pois foram investigados quatro documentos oficiais: Decreto 9.765/2019 (BRASIL, 2019b); Política Nacional de Alfabetização (BRASIL, 2019a); Portaria 421/2020 (BRASIL, 2020); e Conta Pra Mim: guia de literacia familiar (BRASIL, 2019c). Tais documentos revelam um flagrante da história em produção da política de alfabetização brasileira, marcada pelo enfrentamento e deslegitimação da literatura científica brasileira e estrangeira sob a denominação de estudos dos letramentos, constituídos por pesquisas interpretativistas de base antropológica, conforme mostrado por Silva (2019; 2021).

12 Conforme Kleiman e Assis (2016, p.13), "a unidade básica de análise para entender o impacto da escrita na sociedade não é o texto, mas o evento de letramento: uma situação comunicativa única realizada em um contexto físico específico de uma determinada esfera de ação, com participantes singulares engajados em atividades que os motivam, as quais estes realizam mobilizando práticas de letramento para lidar com o texto escrito e outros artefatos culturais (computadores, mapas, papel etc.) e fazer sentido da situação, na qual o texto escrito circula ou está como pano de fundo, subentendido".

13 Segundo o Decreto n 9.765/2019, no Capítulo IV, Parágrafo único: "São beneficiários prioritários da Política Nacional de Alfabetização os grupos a que se referem os incisos I e II do caput: I. crianças na primeira infância; II. alunos dos anos iniciais do ensino fundamental" (BRASIL, 2019b). 
Os documentos selecionados foram analisados a partir da nossa leitura crítica, informada por referenciais teóricos originários predominantemente dos estudos dos letramentos, os quais foram revisados na seção anterior. Nesse sentido, também consideramos este estudo como uma pesquisa bibliográfica, pois, previamente, investigamos como algumas literaturas especializadas concebem os denominados letramentos familiares e emergentes, dois conceitos constitutivos da política de alfabetização investigada, ainda que nela tenha sido utilizada a nomenclatura literacia, evidenciando o enfrentamento mencionado. Assim, empregamos a abordagem qualitativa para análise dos documentos.

O principal documento analisado foi o guia de literacia familiar Conta Pra Mim (BRASIL, 2019c), criado pela secretaria de Alfabetização do MEC, destinado a "todas as famílias brasileiras, tendo prioridade aquelas em condição de vulnerabilidade socioeconômica", conforme Art. $2^{\circ}$, da Portaria 421/2020 (BRASIL, 2020). O referido guia apresenta dicas de como praticar o que é denominado de literacia familiar. Foi publicado no segundo semestre de 2019, assim como o caderno da PNA (BRASIL, 2019a), sendo ambos amparados pelo Decreto 9.765/2019 (BRASIL, 2019b), marco legal da política oficial para alfabetização. A Portaria 421/2020 (BRASIL, 2020), que institui o programa Conta Pra Mim, só foi publicada no primeiro semestre de $2020^{14}$. Na Figura 2, representamos essa configuração da política de alfabetização.

Figura 2 - Política Nacional de Alfabetização
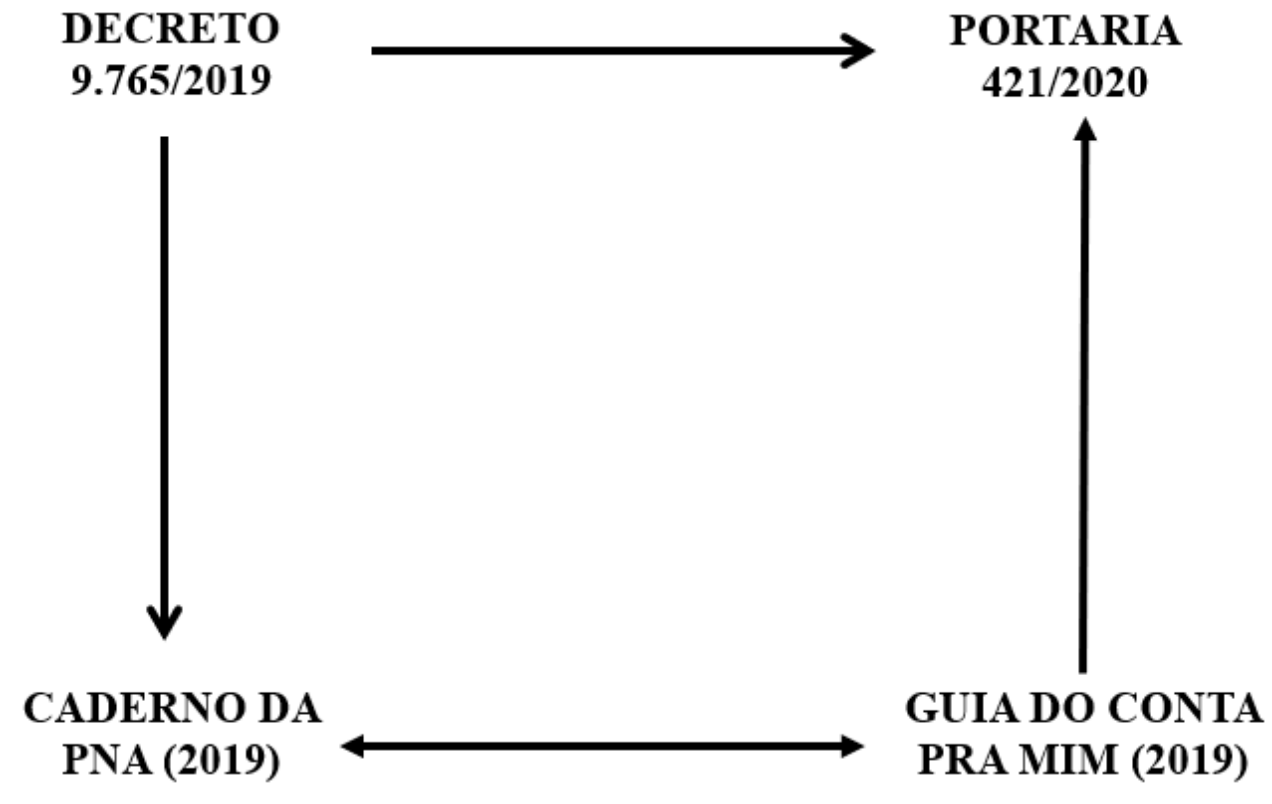

Fonte: Autoria própria

O Decreto 9.765/2019 (BRASIL, 2019b) definiu a criação do programa que levou a instituição da PNA (BRASIL, 2019a, p.7), com a proposta de "elevar a qualidade da alfabetização e combater o analfabetismo em todo o território brasileiro". Para a elaboração do caderno, conforme ainda consta na apresentação do documento, foram levadas em consideração "experiências exitosas de estados e municípios brasileiros e de outros países que formularam suas políticas públicas de alfabetização com base em evidências científicas, e melhoraram os indicadores não só de leitura e escrita, mas também de matemática" (BRASIL, 2019a, p. 7). Conforme dito previamente, essa noção de evidência científica foi problematizada e questionada por Silva (2021).

14 A cronologia de publicação dos documentos aqui analisados é: abril/2019 - Decreto; agosto/2019 - Caderno da PNA; dezembro/2019 - Guia do Conta Pra Mim; abril/2020 - Portaria. Disponível em: <https://www.gazetadopovo.com.br/educacao/como-o-investimento-do-mec-em-literacia-familiar-pode-mudar-o-futuro-de-familias-pobres/amp/>. Acesso em: 10 jan. 2021. 
O Conta Pra Mim (BRASIL, 2019c) se constitui como um "programa de literacia familiar do Governo federal" (BRASIL, 2020). Foi idealizado a fim de orientar e oferecer dicas para as famílias implementarem práticas legitimadas de literacia familiar. Além do guia, os seguintes materiais foram disponibilizados no portal do MEC para as famílias: séries de vídeos com instruções de como promover a literacia familiar, com cantigas populares cantadas por Toquinho (versão em Libras) e com Fábulas de Monteiro Lobato narradas por Toquinho (versão em Libras); áudios com histórias infantis e contos de fadas; e coleção de livros infantis para ler on-line ou imprimir ${ }^{15}$.

No guia focalizado neste estudo, os responsáveis pelas crianças são tratados como pais ou cuidadores, mas afinal, quem são os pais, figuras parentais ou cuidadores da criança? Em uma sociedade plural, com várias composições familiares, em alguns momentos, o documento parece desconsiderar as muitas crianças que não tem pais, pois moram com tios, avós ou somente com a mãe ou pai, e, às vezes, não possuem parentes saguíneos, há criancas que, por exemplo, moram em abrigos. São diversas as composições familiares e o assunto merece ser tematizado com bastante zelo e respeito em um documento que se pretende configurar como uma política de governo para o que denominam literacia familiar.

A observação atenta da sociedade brasileira, garantida especialmente quando transitamos ou, até mesmo, estamos inseridos em comunidades excluídas, permite-nos afirmar que os cuidadores podem ser alguém da própria família como o avô ou a avó que cuida dos netos, a irmã ou o irmão maior que cuida dos outros menores, a vizinha ou o vizinho, o pai, a mãe, o padrasto ou a madrasta que está desempregado(a). Muitas vezes, o cuidador é aquela pessoa que acabou sobrando por dispor de mais tempo, pode não ser a pessoa ideal, mas é o 'voluntário' com quem as famílias pobres podem contar num dado momento.

Para as famílias abastadas que custeiam o serviço doméstico, as babás ou cuidadoras das crianças, frequentemene, são pessoas que moram em lugares periféricos, não têm com quem deixar os próprios filhos ${ }^{16}$, são pessoas pobres, com pouca escolarização, algumas podem ser analfabetas ou abandonaram a escola precocemente para trabalhar. Em outros casos, os cuidadores podem ser o público da Educação de Jovens e Adultos (EJA) despretigiado na PNA (BRASIL, 2019a). Diante destes perfis, percebemos que as trabalhadoras domésticas podem não ter formação específica para exercer a função do que podemos denominar de 'alfabetizadoras domésticas' de crianças privilegiadas economicamente. Enquanto as mães pobres estão trabalhando, os seus filhos podem não ter com quem fazer as atividades escolares ou as práticas descritas em programas oficiais.

Conforme passamos a examinar na próxima seção deste artigo, o guia de orientação para as famílias tem como principais práticas de literacia familiar: Interpretação verbal; Leitura dialogada; Narração de histórias; Contatos com a escrita; Atividades diversas; e Motivação.

\section{ESCOLARIZAÇÃO DE INTERAÇÕES FAMILIARES}

Os documentos revelam que a literacia familiar contribui para o desenvolvimento de habilidades necessárias à participação de crianças em práticas de oralidade, leitura e escrita. Os "pais, familiares ou cuidadores" são identificados como os responsáveis por promover as práticas de literacia familiar, que poderão facilitar, posteriormente, o processo de alfabetização das crianças. No Quadro 1, justapomos o conceito de literacia familiar assumido nos documentos oficiais da política de alfabetização. Os excertos revelam a retextualização ou replicação de um mesmo conceito em documentos diferentes.

15 Disponível em: <http://alfabetizacao.mec.gov.br/contapramim\#materiais>. Acesso em: 10 jan. 2021.

16 A título de ilustração, registramos a fatalidade ocorrida com Miguel Otávio Santana da Silva, criança de cinco anos, vitimado por uma queda do $9^{\circ}$ andar de um prédio de luxo no centro do Recife, Estado de Pernambuco. O menino estava sob os cuidados da então patroa da mãe e da avó, no momento em que a mãe prestava serviços domésticos na residência da referida patroa. A criança estava no local de trabalho da mãe pelo fato de a creche por ele frequentada está fechada devido à pandemia da Covid-19. Disponível em: <https://noticias.uol.com.br/cotidiano/ultimas-noticias/2020/08/19/ex-patroa-e-citada-em-processo-da-morte-de-miguel-e-tem-10-dias-para-defesa.htm>. Acesso em: 10 jan. 2021. 
Quadro 1 - Conceito de literacia familiar nos documentos oficiais

\begin{tabular}{|c|c|}
\hline DECRETO & PNA \\
\hline $\begin{array}{l}\text { Conjunto de práticas e experiên- } \\
\text { cias relacionadas com a lingua- } \\
\text { gem, a leitura e a escrita, as quais } \\
\text { a criança vivencia com seus pais } \\
\text { ou cuidadores (Cap. I, Art. } 2^{\circ} \text {, Alí- } \\
\text { nea VIII). }\end{array}$ & $\begin{array}{l}\text { O êxito das crianças na aprendizagem da leitura e da } \\
\text { escrita está fortemente vinculado ao ambiente familiar } \\
\text { e às práticas e experiências relacionadas à linguagem, } \\
\text { à leitura e à escrita que elas vivenciam com seus pais, } \\
\text { familiares ou cuidadores, mesmo antes do ingresso no } \\
\text { ensino formal (BRASIL, 2019a, p.23). }\end{array}$ \\
\hline PORTARIA & CONTA PRA MIM \\
\hline $\begin{array}{l}\text { Conjunto de práticas e experiên- } \\
\text { cias relacionadas com a lingua- } \\
\text { gem, a leitura e a escrita, as quais } \\
\text { a criança vivencia com seus pais } \\
\text { ou cuidadores (Cap. I, Art. } 3^{\circ} \text {, Alí- } \\
\text { nea III). }\end{array}$ & $\begin{array}{l}\text { É o conjunto de práticas e experiências relacionadas } \\
\text { com a linguagem oral, a leitura e a escrita, que as } \\
\text { crianças vivenciam com seus pais ou responsáveis } \\
\text { (BRASIL, 2020c, p.13). }\end{array}$ \\
\hline
\end{tabular}

Está registrado nos documentos que práticas de leitura e escrita devem ser desenvolvidas pelas famílias. Entretanto, destacamos que algumas práticas elencadas são típicas do trabalho pedagógico especializado realizado na Educação Infantil, portanto, demandam uma instrução profissional, constituem práticas características do espaço institucional de educação formal. Em outras palavras, podemos afirmar que se trabalha no limite da escolarização de letramentos familiares. A política oficial promove uma formalização das práticas interativas nos lares, mesmo que, no documento, possamos encontrar informações do seguinte tipo, demonstrando que o risco da "pedagogização" evidentemente existe: "Não transforme o contato com seu filho em um momento formal de ensino" (BRASIL, 2019c, p. 25$)^{17}$.

O guia focalizado faz o seguinte apontamento sobre a participação da família no processo de alfabetização, responsabilizando os familiares pela educação das crianças e minimizando a influência de algumas situações adversas enfrentadas:

Estudos mostram que as ações no seio familiar são mais importantes do que a renda ou a escolaridade da família. Isso é válido para crianças de diferentes etapas da educação básica, quer sua família seja rica ou pobre, quer seus pais tenham ou não terminado o ensino médio (BRASIL, 2019c, p. 8).

Não podemos negar a importância das famílias na promoção de práticas de letramentos, mas devemos evitar as tentativas de homogeneização de interações familiares no contexto brasileiro marcado por culturas diferenciadas e desigualdades sociais. Há famílias abastadas que leem para seus filhos, assim como há famílias desfavorecidas economicamente que cultivam práticas de leitura, ambas podem não compartilhar as mesmas preferências, mas devem ter as respectivas escolhas legitimadas. Cagliari (1986, p. 29), linguista de formação, ao problematizar a alfabetização e a pobreza no Brasil, afirma que "Numa comunidade pobre de periferia, o pouco dinheiro que aparece é precioso demais e precisa ser usado para a comida, não para manter a escola". Ora, se há famílias que precisam optar entre a comida e a compra de algum material escolar, portanto, não podemos afirmar que as ações familiares independem da renda.

17 Segue um exemplo de interação verbal entre familiares e crianças próximas às práticas escolares: "Chame a atenção da criança para os sons das palavras e das letras: 'Filha, seu nome é Vitória, que começa com a letra 'V'. Qual é o som da letra 'V'? Muito bem! É [V-V-V-v]!', 'Filho, vamos ver quem encontrará mais coisas no supermercado que rimam com limão? Achei uma: mamão!'” (BRASIL, 2019c, p. 28). 
Na política de alfabetização, parece haver alguma contradição em relação ao conteúdo do excerto supramencionado (BRASIL, 2019c). As famílias pobres estão propensas a possuírem alguma desvantagem no tocante ao envolvimento das crianças na cultura legitimada da escrita. Essa desvantagem é reconhecida no seguinte excerto, que tematiza os principais beneficiários da política oficial:

Os principais beneficiários são as famílias de nível socioeconômico mais baixo, cujas crianças se encontram em desvantagem com relação às demais (TUNMER, 2013; SÉNÉCHAL, 2008). Até mesmo pais ou cuidadores não alfabetizados podem realizar práticas simples e eficazes de literacia familiar quando bem orientados (CARPENTIERI et al., 2011). (BRASIL, 2019a, p. 23).

Destacamos a existência de evidências sustentando uma relação direta entre a renda familiar e a alfabetização das crianças. Orientada pelo modelo autônomo de letramento, há uma crença em que a participação da família no processo de letramento possibilita superar as adversidades ou desafios da alfabetização e, consequentemente, asseguraria a superação de problemas relacionados a saúde, segurança, emprego, dentre outros fatores que atingem principalmente as classes sociais vulneráveis. Sobre essa questão Haddad e Di Pierro (2000, p.31) afirmam:

O analfabetismo no Brasil não é, pois, apenas um problema residual herdado do passado (suscetível de tratamento emergencial ou passível de superação mediante a simples sucessão geracional), e sim uma questão complexa do presente, que exige políticas públicas consistentes, duradouras e articuladas a outras estratégias de desenvolvimento econômico, social e cultural.

É importante a promoção de políticas públicas comprometidas com o preparo das crianças para a alfabetização, considerando a participação das famílias e o trabalho qualificado da Educação Infantil. As políticas devem promover formação continuada consistente às alfabetizadoras, fortalecendo a autonomia necessária às referidas profissionais para atuarem no local de trabalho e não exigindo das profissionais a observância pacífica de roteiros de aulas produzidos por outrem. Faz-se necessário também a promoção de políticas sociais para assegurar às famílias acesso a saneamento básico, serviços de saúde, além de assegurar à população, quando necessário, alguma assistência financeira, a exemplo das demandas sociais agravadas com a pandemia da Covid-19.

No Conta Pra Mim, a literacia familiar parece supervalorizada, pois o contexto social vivenciado pelos brasileiros não é concebido em sua complexidade: "Em um país como o Brasil, ainda marcado pela condição socioeconômica desfavorável de milhões de famílias, a Literacia Familiar é um instrumento poderoso para romper o ciclo da pobreza" (BRASIL, 2019c, p.17). Afirmações desse tipo propagam mitos em torno das práticas de leitura e escrita legitimadas na política focalizada, reproduzindo o que reconhecemos como modelo autônomo de letramento.

Além disso, no documento, não há evidências de valorização dos costumes ou vivências características das localidades mais remotas, distantes dos centros urbanos. A diversidade cultural do imenso território brasileiro, muitas vezes marcada por práticas da oralidade, não pode ser ignorada, a exemplo das interações mediadas por cantigas ou jogos de linguagens locais, cordéis e repentes, gêneros característicos das literaturas populares. A política de alfabetização valoriza algumas práticas letradas legitimadas, no entanto, não podemos depositar nossa esperança de realização pessoal ou profissional exclusivamente na cultura escrita. 
Ademais, linguagem, contexto, imagens, representação de famílias, casas e o mascote do programa se distanciam da realidade do povo brasileiro. A divulgação do material está em sites, propagandas veiculadas na televisão e também percorreu os shoppings das principais capitais do Brasil, conforme ilustrado na Figura 3.

Figura 3 - Agenda de divulgação do programa Conta Pra Mim
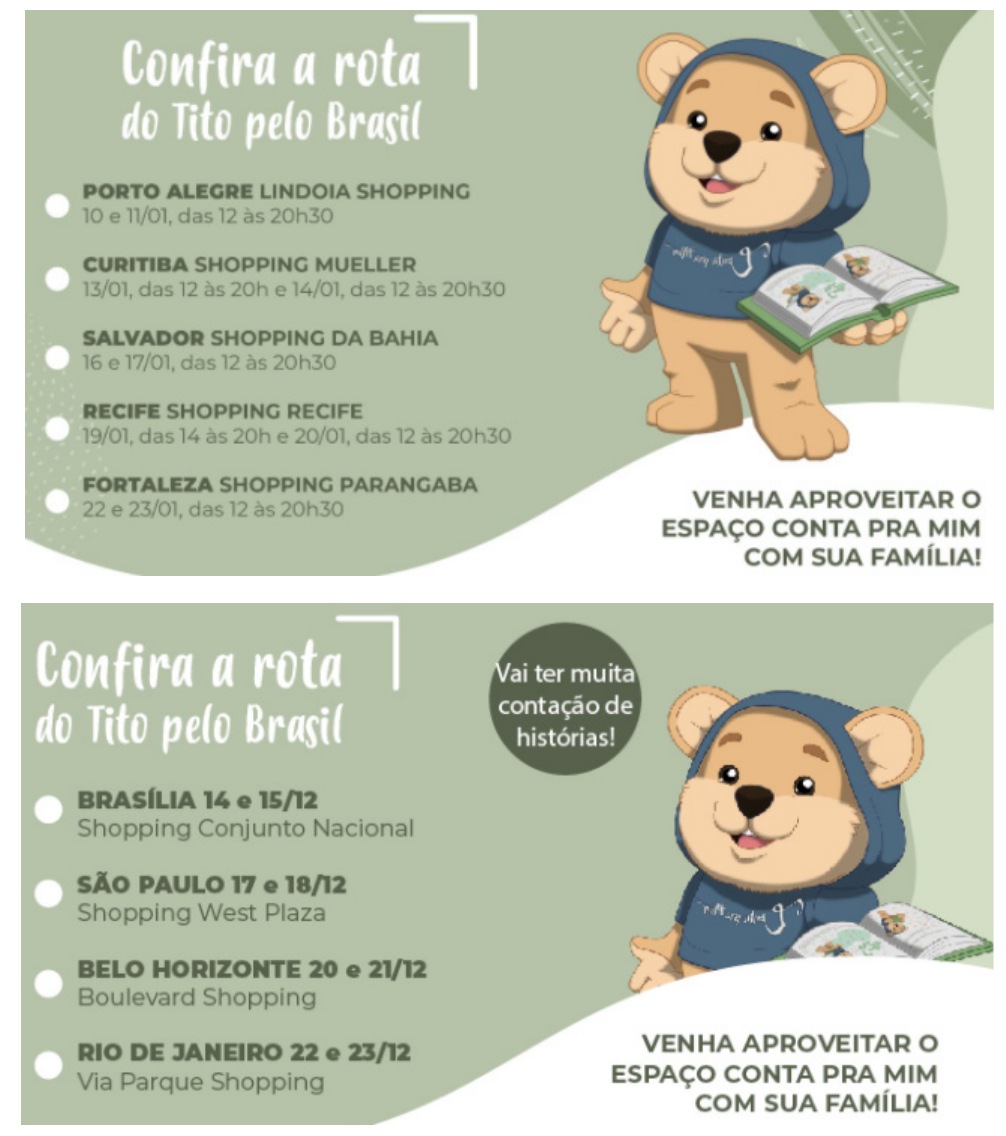

Fonte: Portal do MEC ${ }^{18}$

Tendo como público alvo a população de baixa renda, os shoppings não são os melhores espaços para o governo ir ao encontro dessas famílias. Dificilmente, elas moram próximas aos grandes centros, mas, geralmente, residem em periferias. Reconhecemos situações em que famílias em vulnerabilidade social residem na vizinhança dos referidos centros de compras, mas são moradias irregulares, as denominadas comunidades ou favelas, portanto, esses cidadãos se tornam facilmente passíveis do enfrentamento de situações preconceituosas em que negros ou pobres são confundidos com delinquentes ${ }^{19}$. Consta no documento da PNA (BRASIL, 2019a) a criação do programa de literacia familiar, com a justificativa de promover o sucesso escolar da criança:

Implementar programas e ações de literacia familiar como medidas preventivas do insucesso escolar tem sido uma estratégia empregada em diversos países. Esses programas e ações, em geral, objetivam encorajar pais ou cuidadores a desempenharem um papel mais ativo no desenvolvimento da literacia das crianças em idade pré-escolar (BRASIL, 2019a, p. 23).

18 Disponível em: http://portal.mec.gov.br/component/tags/tag/54161. Acesso em: 10 jan. 2021.

19 Recentemente, um jovem negro de 18 anos foi vítima de racismo ao ser imobilizado em um shopping na zona norte do Rio de Janeiro. Ele foi trocar um relógio comprado para presentear o pai. Seguem dois enunciados ilustrativos do caso: "Eu sei que tudo isso foi por causa da minha cor. Em nenhum momento deixaram que eu mostrasse a nota fiscal do produto', disse o rapaz"; "'Ele foi abordado por ser negro. Vamos ouvir funcionários da loja e do shopping para tentar identificar os agressores". "O crime de racismo está claro, afirmou o delegado". Disponível em: https://www. cnnbrasil.com.br/nacional/2020/08/07/jovem-negro-e-vitima-de-racismo-ao-tentar-trocar-relogio-em-shopping-do-rio. Acesso em: 10 jan. 2021. 
A política recomenda que os responsáveis pelas crianças sejam mais participativos no desenvolvimento de práticas de letramentos familiares, o que pode resultar na minimização da responsabilidade do governo no tocante à oferta compulsória da educação formal de qualidade, resultando ainda na responsabilização das famílias pelo possível fracasso escolar. Essa iniciativa também demonstra o silenciamento do governo diante de outras demandas sociais que afetam direta ou indiretamente a trajetória das crianças nas escolas.

Insistimos que, na política focalizada, as famílias são concebidas com alguma homogeneidade, mesmo em um país com enorme diversidade cultural e desigualdade social, com uma população vitimada pela escassez de políticas públicas eficazes, que assegurem efetivamente a dignidade às pessoas, garantindo a participação das famílias na vida escolar das crianças. Legitimar experiências promissoras em outros países, com demandas distintas da realidade brasileira, pode significar a continuidade da promoção de resultados que comprometem o futuro das crianças locais. Na PNA (BRASIL, 2019a), pesquisas brasileiras que apresentam experiências bem-sucedidas alinhadas a especificidades nacionais foram menosprezadas, em detrimento de influências internacionais (SILVA, 2021).

No Quadro 2, reproduzimos algumas sequências textuais com "habilidades, atitudes e conhecimentos" elencadas no guia Conta Pra Mim (BRASIL, 2019c, p. 19) como "Facilitadores da Alfabetização". São sequências reunidas em função do desenvolvimento da oralidade e trazem alguns equívocos conceituais, quando observados a partir de postulados teóricos de estudos linguísticos aplicados, ou indícios de motivação da pedagogização de interações familiares, haja vista a especialização de conhecimentos demandados.

Quadro 2 - Formalização das práticas familiares

\begin{tabular}{|l|l|}
\hline $\begin{array}{l}\text { Desenvolvimento da } \\
\text { linguagem oral }\end{array}$ & $\begin{array}{l}\text { Desse modo, é importante que a criança chegue à escola com as habilida- } \\
\text { des de linguagem oral consolidadas. (BRASIL, 2019c, p. 19) }\end{array}$ \\
\hline Compreensão oral & $\begin{array}{l}\text { Não é possível compreender o que se lê, sem antes ser capaz de com- } \\
\text { preender o que se escuta. Depois de consolidadas, as habilidades de } \\
\text { compreensão oral também são usadas na leitura. (BRASIL, 2019c, p.20) }\end{array}$ \\
\hline $\begin{array}{l}\text { Familiaridade } \\
\text { com as estruturas } \\
\text { gramaticais da } \\
\text { língua }\end{array}$ & $\begin{array}{l}\text { Familiaridade com as estruturas gramaticais da língua consiste na habili- } \\
\text { dade de compreender a estrutura de uma sentença, como tempo verbal, } \\
\text { sujeito e objeto. A sintaxe é importante, pois a posição das palavras altera o } \\
\text { significado das frases. [...] Quanto mais sofisticado e gramaticalmente cor- } \\
\text { reto for o discurso dos pais, mais será o da criança. (BRASIL, 2019c, p.21) }\end{array}$ \\
\hline
\end{tabular}

As duas primeiras sequências revelam o modelo autônomo de letramento influenciando a política. O que significaria chegar à escola com a oralidade consolidada? Não podemos nos esquecer de que as práticas de linguagens são dinâmicas, renovam-se continuamente junto às ininterruptas transformações sociais. Nesse sentido, o aprendizado se desenvolve ao longo da vida. A oralidade pode se realizar em situações mais ou menos formais, mais ou menos planejadas, configura-se como uma das práticas de linguagem a serem trabalhadas e aprimoradas na escola, especialmente em aulas de Língua Portuguesa. Por isso, a oralidade é um dos eixos orientadores do planejamento escolar (além dos da leitura, produção de textos e análise linguística/semiótica), propostos na Base Nacional Comum Curricular - BNCC (BRASIL, 2018) para os Ensinos Fundamental e Médio.

As primeiras sequências reproduzidas no Quadro 2, podem fortalecer a crença na oralidade como modalidade linguística de menor prestígio, caracterizada por habilidades primárias a serem apropriadas para o alcance das habilidades constitutivas das práticas de leitura e escrita. Se "não é possível compreender o que se lê, sem antes ser capaz de compreender o que se escuta", pressupondo que estão se referindo especificamente à leitura de textos escritos, as crianças surdas estariam fadadas ao fracasso escolar ou todas teriam que se submeter à oralização compulsória para escapar dele? 
A terceira sequência nos chama a atenção por dois aspectos principais: (1) demandar algum conhecimento explícito e especializado sobre a morfossintaxe do português por parte de familiares ou cuidadores, considerando ainda os efeitos semântico-discursivos produzidos pelo trabalho sobre a estrutura linguística; (2) fortalecer o preconceito linguístico entre os brasileiros, pois se fala em sofisticação e correção gramatical, ignorando-se condicionantes contextuais e culturais, o que, certamente, poderia ser trabalhado adequadamente por professoras especialistas no assunto.

Na política focalizada, as práticas de literacia familiar são as habilidades a serem desenvolvidas pelas crianças a fim de que o processo de alfabetização seja facilitado. Na Figura 4, reproduzimos as práticas de literacia familiar apresentadas em tópicos no documento. Elas devem ser trabalhadas com alguma sistematização pelas famílias ou cuidadores junto às crianças.

Figura 4 - Práticas de Literacia Familiar

\section{Quais são as práticas de Literacia Familiar}
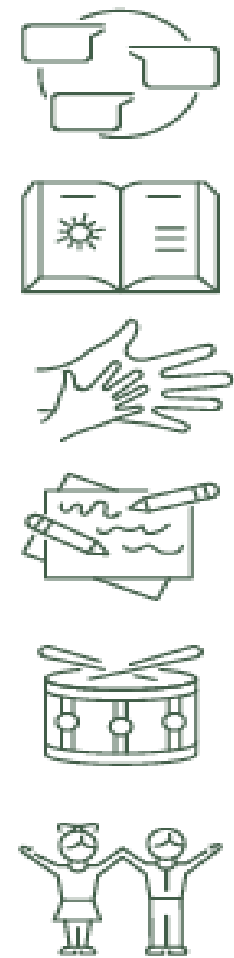

INTERAÇAO VERBAL

aumentar a quantidade e a qualidade dos diálogos com as crianças

\section{LEITURA DIALOGADA}

interagir com a criança durante a leitura em voz alta

NARRAÇĀO DE HISTORIAS

interagir com a criança durante a narração de histórias

\section{CONTATOS COM A ESCRITA} familiarizar as crianças com a escrita

\section{ATIVIDADES DIVERSAS}

jogar, brincar, cantar, tocar instrumentos musicais, interpretar, dançar, passear, viajar.

\section{MOTIVAÇÃO}

aumentar a motivação das crianças em relação à leitura e à escrita

Fonte: Conta Pra Mim (BRASIL, 2019c, p. 14)

Quando apresentas em tópicos, as práticas de literacia familiar parecem ser bastante proveitosas para as interações nos lares, porém, nas descrições detalhadas, incluído aí o que se denomina "dicas simples, baratas e eficientes" (BRASIL, 2019c, p. 38), encontramos alguns conteúdos curriculares ou elementos programáticos da escola, que, mais uma vez, nos termos de Freire (2008, p. 32), são "objetos cognoscíveis, objetos estes que os jovens que se formam para ser professor ou professora devem conhecer". Assim, essas práticas de literacia familiar podem ser apreendidas pelas crianças 
espontaneamente quando inseridas em projetos de letramentos ${ }^{20}$ a partir da Educação Infantil, sem a necessidade da indução das famílias como professoras dos filhos: "Literacia Familiar é o reconhecimento de que os pais são os primeiros professores de seus filhos" (BRASIL, 2019c, p.13). No excerto do Quadro 3, exemplificamos uma das dicas que podem promover o que estamos denominando escolarização das interações nos lares.

Quadro 3 - Leitura dialogada

Aponte para as letras e os sinais de pontuação presentes nas páginas. Chame a atenção
de seu filho tanto para os sons, os nomes e as formas das letras quanto para as funções
dos sinais de pontuação: "Que sinal de pontuação usamos para indicar uma pergunta?
Mostre-o no livro para a mamãe!", "Filha, veja! Uma letra pode ter formas e tamanhos
diferentes. Existem letras maiúsculas e minúsculas. Você já notou que seu nome começa
com uma letra maiúscula?" (BRASIL, 2019c, p.42)

No excerto do Quadro 3, a maneira como se descreve a interação mediada pela leitura nos lembra de algumas práticas pedagógicas. A recorrência de dicas desse tipo pode minimizar a relevância do contato das crianças com livros ou revistas infantis, por exemplo. Por um lado, minimiza-se a leitura mais descompromissada, as construções de hipóteses sobre narrativas, a produção de fantasias e, por outro lado, torna-se a leitura uma prática focada em habilidades técnicas, realçando-se os usos de sinais de pontuação ou relações entre sons e elementos gráficos.

Nos excertos do Quadro 4, ilustramos uma dica que julgamos mais proveitosa e outra que demanda mais controle ou vigilância na interação por parte de familiares ou cuidadores.

Quadro 4 - Práticas de Literacia Familiar

\begin{tabular}{|l|}
\hline Crianças pequenas gostam de repetição: leia e releia a mesma história para elas várias \\
vezes. A cada releitura as crianças descobrem coisas novas. (BRASIL, 2019c, p.42). \\
\hline São tantas e tão ricas as estratégias de Leitura Dialogada que podemos ler uma mesma \\
história várias vezes e com diferentes objetivos: ora focando o enredo, ora o vocabulá- \\
rio, ora os sons das letras, ora os sentimentos das personagens, etc. (BRASIL, 2019c, \\
p.48; destaque do original) \\
\hline
\end{tabular}

Na primeira dica do Quadro 4, enfatiza-se o prazer ou deleite proporcionado pela leitura descompromissada, proporcionando-se a construção de fantasias e a criação de hipóteses pelos interactantes, considerando-se ainda desenvolvimento de habilidades de compreensão. No segundo excerto do Quadro 4, há uma proposição interessada no enfoque de aspectos linguísticos ou em elementos da narrativa lida. Pressupomos que o conhecimento linguístico tematizado na segunda sequência estaria alinhado ao que compreendemos por letramentos emergentes, envolvendo práticas formativas no contexto da Educação Infantil, conforme proposto cuidadosamente por Viana, Ribeiro e Barrera (2017), o que não significa a antecipação precoce ou irresponsável da alfabetização.

O enfoque sobre algumas convenções da escrita nos lembra da lista de propriedades do Sistema de Escrita Alfabética (SEA), proposta por Morais (2012) para serem trabalhadas no processo de alfabetização, possibilitando a construção desses conhecimentos pelas crianças com auxílio especializado das alfabetizadoras. Essas propriedades também são ressaltadas por Viana, Ribeiro e Barrera, (2017, p.19-20):

20 Inspirados em Kleiman (2000, p. 18), compreendemos os projetos de letramento na Educação Infantil como situações educativas planejadas por professoras para inserir as crianças naturalmente em práticas sociais informadas pela leitura e escrita, refletindo "situações significativas e relevantes do cotidiano". É importante, inclusive, que esses projetos envolvam não só as famílias, mas a comunidade em que as crianças e as escolas estão inseridas, observando as particularidades socioculturais das localidades. 
Para aprender a ler, a criança precisa saber que as frases são constituídas por palavras; que as palavras, por sua vez, são constituídas por pedacinhos menores, as sílabas; que as sílabas integram constituintes menores, os fonemas. Essa consciência da estrutura segmental da língua e a identificação das unidades menores - sílabas e fonemas - constituem-se como facilitadoras da aprendizagem da leitura em línguas de escrita alfabética. No entanto, se a identificação da sílaba é relativamente fácil em português, língua em que a maioria das sílabas tem uma estrutura formada por consoante + vogal, facilmente identificável na corrente acústica, a identificação dos fonemas que constituem as sílabas é uma tarefa difícil e só efetuada plenamente com êxito após a aprendizagem formal da leitura. Isto é, se quando do início da aprendizagem formal da leitura e da escrita o aprendiz possuir alguma capacidade de análise da linguagem oral em termos dos seus constituintes sonoros, o trabalho será facilitado.

Ressaltamos que o conhecimento dessas propriedades ou convenções pode ser construído, a depender dos perfis dos envolvidos, a partir de práticas de letramentos emergentes na Educação Infantil. O processo de alfabetização é bastante complexo e demanda o conhecimento especializado das alfabetizadoras. Os documentos investigados podem corroborar para a desvalorização desse conhecimento e, consequentemente, reforçar a crença de que a prática de alfabetização se caracteriza pela simplicidade, podendo ser assumida por qualquer pessoa fluente na língua e escolarizada.

Em nossa experiência profissional, observamos que, muitas vezes, o conhecimento linguístico necessário à profissional da alfabetização é buscado em cursos de especialização em estudos da linguagem, haja vista o espaço reduzido em Licenciaturas em Pedagogia para o trabalho com os objetos cognoscíveis dos componentes curriculares da Educação Básica. É o profissional da educação que atua no ensino formal desde a Educação Infantil, desenvolvendo a aprendizagem das crianças, trabalhando para complementar a formação delas, envolvendo aspectos sociais, psicológicos, intelectuais, dentre outros... A família e a escola ocupam espaços distintos na vida das crianças, ambas funcionam como agências de letramentos desenvolvendo funções complementares.

\section{CONSIDERAÇÕES FINAIS}

No presente texto, investigamos o conceito de literacia familiar nos documentos que constituem a atual política brasileira de alfabetização (BRASIL, 2019a; 2019b; 2019c; 2020), com o propósito de compreender o que esse conceito representa, diante de algumas pesquisas científicas dos estudos dos letramentos. Este texto foi concebido para contribuir com o aprimoramento profissional das alfabetizadoras e das professoras em formação inicial.

Nos documentos oficiais, o conceito de literacia familiar se confunde com práticas pedagógicas da educação formal, as quais, como sugerem, deveriam ser desenvolvidas por pais ou cuidadores. Tal concepção se aproxima do que compreendemos por letramentos emergentes, práticas interativas mediadas pela leitura e escrita, características do trabalho pedagógico de professoras na Educação Infantil, com propósito de desenvolver habilidades linguísticas das crianças. Essas práticas possibilitam inclusive a construção espontânea do conhecimento de propriedades do sistema da escrita, necessárias ao processo formal, consciente e produtivo de alfabetização.

Na política focalizada, a literacia familiar corresponde a práticas legitimadas para o desenvolvimento da oralidade e da escrita pelas crianças em seus lares. Essas práticas se caracterizam por procedimentos escolarizados, repetitivos e, algumas vezes, informados por pressupostos teóricos questionáveis diante da produção científica dos estudos linguísticos. Na literatura especializada consultada, no entanto, os letramentos familiares são atividades sociais mais espontâneas mediadas pela 
tecnologia da escrita, são relevantes na formação integral das crianças, a exemplo do desenvolvimento de vínculos afetivos com os adultos. Em outros termos, os letramentos familiares não são apenas relevantes para o processo de alfabetização. A unanimidade existente é a esperança de que todas as crianças sejam capazes de ler e escrever ao final do processo mencionado.

A política de literacia familiar está efetivamente a serviço das famílias? Por um lado, os pais ou os cuidadores desejam futuros promissores para suas crianças. Eles compartilham a esperança da realização pessoal e profissional dos próprios filhos. Por outro lado, por restrições diversas e complexas, esses pais e cuidadores poderão se verem impossibilitados de implementarem a política oficial de literacia. Essa parece ignorar as complexas adversidades enfrentadas pelas diferentes famílias nos lugares mais distantes do imenso território brasileiro. Não acreditamos que a solução para parte relevante dos desafios da educação brasileira esteja no tipo de programa de literacia familiar apresentado, o qual atribui significativa responsabilidade pelo sucesso escolar das crianças às famílias, independentemente das condições sociais ou dos desafios enfrentados diariamente por elas. Condições e desafios que, reiteramos, pareceram-nos ignorados nos documentos.

Finalmente, a política poderia esclarecer os responsáveis pelas crianças a respeito das contribuições das professoras para as práticas de letramentos familiares, minimizando a possibilidade da compreensão de que, pelos resultados indesejados da educação formal, caberia aos pais ou cuidadores assumirem as legítimas funções das professoras. Para a promoção dos letramentos familiares, reconhecemos a relevância das escolas e sabemos da existência de instituições públicas brasileiras de ensino que funcionam como agências promotoras desses letramentos, mesmo não assumindo tal denominação. Enquanto objeto de pesquisa, a abordagem dos letramentos familiares parece promissora para os estudos científicos indisciplinares sobre culturas da escrita.

\section{REFERÊNCIAS}

BARRERA, Sylvia; RIBEIRO, Iolanda; VIANA, Fernanda. Desenvolvendo competências de letramento emergente: inserção do programa DECOLE no contexto da educação infantil no Brasil. In: VIANA, Fernanda; RIBEIRO, Iolanda; BARRERA, Sylvia. (Org.). DECOLE - Desenvolvendo Competências de Letramento Emergente: propostas integradoras para a pré-escola. Porto Alegre: Penso, 2017. p. 1-16.

BRASIL. Planejando a próxima década: conhecendo as 20 metas do Plano Nacional de Educação. Brasília: Ministério da Educação, 2015. 60 p. Fonte: http://pne.mec.gov.br/images/pdf/pne_conhecendo_20_metas.pdf. Acesso em: 04 jul. 2020.

BRASIL. Base Nacional Comum Curricular. Brasília: MEC, 2018. Fonte: http://basenacionalcomum.mec.gov.br/. Acesso em: 12 set. 2020.

BRASIL. Ministério da Educação. Secretaria de Alfabetização. PNA Política Nacional de Alfabetização. Brasília: MEC, SEALF, 2019a. 54 p. Fonte: http://alfabetizacao.mec.gov.br/politica-nacional-de-alfabetizacao-2/ publicacoes. Acesso em: 12 set. 2020.

BRASIL. Presidência da República. Decreto 9.765, de 11 de abril de 2019. Brasília, 2019b. Fonte: https://www. in.gov.br/materia/-/asset_publisher/KujrwOTZC2Mb/content/ id/71137476/do1e-2019-04-11-decreto-n-9-765-de11-de-abril-de-201971137431. Acesso em: 12 set. 2020.

BRASIL. Ministério da Educação. Secretaria de Alfabetização. Conta Pra Mim: Guia e Literatura Familiar. Brasília: MEC, SEALF, 2019c. Fonte: http://alfabetizacao.mec.gov.br/images/pdf/conta-pra-mim-literacia.pdf. Acesso em: 12 set. 2020.

BRASIL. Ministério da Educação. Portaria n 421, de 23 de abril de 2020. Brasília, 2020. Fonte: https://www. in.gov.br/en/web/dou/-/portaria-n-421-de-23-de-abril-de-2020-253758595. Acesso em: 12 set. 2020. 
BRASIL. Constituição da República Federativa do Brasil: D.O. 5 de outubro de 1988. Fonte: http://www.planalto. gov.br/ccivil_03/constituicao/constituicaocompilado.htm. Acesso em: 12 set. 2020.

BRASIL. Lei de Diretrizes e Bases da Educação Nacional. Lei número 9394, 20 de dezembro de 1996. Fonte: http://www.planalto.gov.br/ccivil_03/leis/19394.htm. Acesso em: 12 set. 2020.

BRASIL. Estatuto da Criança e do Adolescente. Lei 8.069/90, de 13 de julho de 1990. Fonte: http://www.planalto. gov.br/ccivil_03/leis//8069.htm. Acesso em: 12 set. 2020.

BRITO, Maria. Escola e família: práticas de letramento, vivências e memórias. 2016. 135f. Dissertação (Mestrado em Estudos da Linguagem) - Centro de Ciências Humanas, Letras e Artes, Universidade Federal do Rio Grande do Norte, Natal.

CAGLIARI, Luiz. Alfabetização e pobreza. Trabalhos em Linguística Aplicada. Campinas: Unicamp, n. 8, v. s/v, p. 25-48, 1986.

COELHO, Isabel. A importância da motivação para a leitura no Pré-escolar. 2011. 81 f. Trabalho de Projeto (Mestrado em Ensino do Português) - Escola Superior de Educação, Escola Politécnica Coimbra, Coimbra.

FREIRE, Paulo. Pedagogia do compromisso: América Latina e educação popular. 1. ed. Indaiatuba: Villa das Letras Editora, 2008.

GOHN, Maria. Educação não-formal, participação da sociedade civil e estruturas colegiadas nas escolas. Ensaio. Avaliação e Políticas Públicas em Educação, Rio de Janeiro, v. 14, n.50, p. 27-38, 2006.

HADDAD, Sérgio; DI PIERRO, Maria. Aprendizagem de jovens e adultos: avaliação da década da educação para todos. São Paulo em Perspectiva, São Paulo: Fundação SEADE,v. 14, n. 1, p. 29-40, 2000. Fonte: https:// www.scielo.br/pdf/spp/v14n1/9800.pdf. Acesso em: 12 set. 2020.

HALLIDAY, Michael; MATTHIESSEN, Christian. M. Halliday's Introduction to Functional Grammar. 4. Ed. London: Routledge, 2014.

KLEIMAN, Angela. (Org.). Ossignificados do letramento: uma nova perspectiva sobre a prática social da escrita. Campinas: Mercado de Letras, 1995.

KLEIMAN, Angela. Histórico da proposta de (auto)formação: confrontos e ajustes de perspectivas. In: KLEIMAN, Angela; SIGNORINI, Inês. (Org.). O ensino e a formação do professor: alfabetização de jovens e adultos. Porto Alegre: Artmed, 2000. p. 17-39.

KLEIMAN, Angela; ASSIS, Juliana. (Org.). Significados e ressignificações do letramento: desdobramentos de uma perspectiva sociocultural sobre a escrita. Campinas: Mercado de Letras, 2016.

KLEIMAN Angela; SIGNORINI, Inês. (Org.). O ensino e a formação do professor: alfabetização de jovens e adultos. Porto Alegre: Artmed, 2000.

MARINHO, Marildes; CARVALHO, Gilcinei. (Org.). Cultura escrita e letramento. Belo Horizonte: Editora da UFMG, 2010.

MATA, Lourdes. Literacia familiar e desenvolvimento de competências de literacia. Exedra Revista Científica Escola Superior de Educação de Coimbra. Português: investigação e ensino, Coimbra, n. s/n, v. v/n, 2012, p. 219-227.

MENDONÇA, Fernanda. Projeto de letramento familiar: um olhar docente. Revista Científica Multidisciplinar Núcleo do Conhecimento. ed. 08, n. 2, v. 1,p. 149-160, 2017 a.

MENDONÇA, Fernanda. Letramento literário: crônicas e contos como instrumentos de humanização do leitor. 2017. 170f. Dissertação (Mestrado em Estudos da Linguagem) - Centro de Ciências Humanas, Letras e Artes, Universidade Federal do Rio Grande do Norte, Natal, 2017b.

MORAIS, Artur. Sistema de escrita alfabética. São Paulo: Melhoramentos, 2012.

MORAIS, Artur. Consciência fonológica na educação infantil e no ciclo de alfabetização. Belo Horizonte: Autêntica, 2019. 
RESENDE, Ana; FIGUEIREDO, Maria. Práticas de literacia familiar: uma estratégia de educação para a saúde para o desenvolvimento integral da criança. Portuguese Journal of Public Health, Lisboa, vol. 36, n.2, 2018, p. 102-113. Fonte: http://www.scielo.mec.pt/pdf/pjph/v36n2/v36n2a07.pdf. Acesso em: 12 set. 2020.

ROJO, Roxane. (Org.). Alfabetização e letramento: perspectivas linguísticas. Campinas: Mercado de Letras, 1998.

SANTOS, Alana. Programa "Engajando famílias na escola": estratégias, possibilidades e desafios. 2015. 232f. Dissertação (Mestrado em Estudos da Linguagem) - Centro de Ciências Humanas, Letras e Artes, Universidade Federal do Rio Grande do Norte, Natal.

SILVA, Wagner. Letramento ou literacia? Ameaças da cientificidade. In: SILVA, Wagner R. (Org.). Contribuições sociais da Linguística Aplicada: uma homenagem a Inês Signorini. Campinas: Pontes, 2021.

SILVA, Wagner. Letramento e fracasso escolar: o ensino da língua materna. 2. ed. Manaus: Editora UEA, 2020.

SILVA, Wagner. Polêmica da alfabetização no Brasil de Paulo Freire. Trabalhos em Linguística Aplicada. Campinas, v. 58, n. 1, p. 219-240, 2019. Fonte: http://dx.doi.org/10.1590/010318138654598480061. Acesso em: 10 jan. 2021.

SOARES, Magda. Alfabetização e letramento. São Paulo: Contexto, 2003a.

SOARES, Magda. Letramento e Escolarização. In: RIBEIRO, V. M. (Org.). Letramento no Brasil. São Paulo: Global Editora, 2003b. p. 89-113.

SOARES, Magda. Alfaletrar. toda criança pode aprender a ler e a escrever. São Paulo: Editora Contexto, 2020.

SOARES, Magda. Alfabetização: a questão dos métodos. São Paulo: Contexto, 2016.

SOARES, Magda. Letramento: um tema em três gêneros. 3. ed. Belo Horizonte: Autêntica Editora, 2009.

STREET, Brian. Os novos estudos sobre o letramento: histórico e perspectivas. In: MARINHO, Marildes; CARVALHO, Gilcinei. (Org.). Cultura escrita e letramento. Belo Horizonte: Editora UFMG, 2010. p. 33-53.

STREET, Brian. Letramentos sociais: abordagens críticas do letramento no desenvolvimento, na etnografia e na educação. São Paulo: Parábola, 2014.

STREET, Brian; STREET, Joanna. A escolarização do letramento. In: STREET, Brian. Letramentos sociais: abordagens críticas do letramento no desenvolvimento, na etnografia e na educação. São Paulo: Parábola, 2014. p. 121-144.

TERZI, Sylvia. A oralidade e a construção da leitura por crianças de meios iletrados. In: KLEIMAN, Angela. Os significados do letramento: uma nova perspectiva sobre a prática social da escrita. Campinas: Mercado de Letras, 1995. p. 91-117.

VIANA, Fernanda; RIBEIRO, Iolanda; BARRERA, Sylvia. (Org.). DECOLE - Desenvolvendo Competências de Letramento Emergente: propostas integradoras para a pré-escola. Porto Alegre: Penso, 2017.

VIANA, Fernanda; CRUZ, Joana; CADIME, Irene. "Ler" antes de ler. Como facilitar a aprendizagem da leitura e da escrita? In: VIANA, Fernanda; RIBEIRO, Iolanda; BARRERA, Sylvia. (Org.). DECOLE - Desenvolvendo Competências de Letramento Emergente: propostas integradoras para a pré-escola. Porto Alegre: Penso, 2017. p. 17-37.

VILHENA, Diana. Literacia familiar: Crenças, práticas e ambientes de literacia em famílias e conhecimento de leitura das crianças no $1^{\circ}$ ano de escolaridade. 2014. 170 f. Dissertação (Psicologia) - Instituto Universitário Ciências Psicológicas, Sociais e da Vida, Lisboa.

Recebido em: 19/0/2020

Aceito em: 12/01/2021 